\title{
O PENSAMENTO HUMANISTA CRISTÃO E ALGUMAS REVERBERAÇÕES NA PEDAGOGIA FREIREANA*
}

\author{
Bárbara Hees Garré*** \\ Paula Corrêa Henning ****
}

\begin{abstract}
RESUMO
O artigo compõe uma dissertação que tem como problema de pesquisa investigar quais discursos de humanismo produzem o campo da educação, na perspectiva freireana. A escolha do corpus discursivo situa-se no entendimento de que Paulo Freire é um autor muito potente no campo da educação, sendo referência básica nos Planos de Ensino e nos Currículos dos cursos que formam professores. Aqui, pretende-se remontar algumas pistas genealógicas que se constituem como condição de possibilidade para a emergência de um pensamento humanista cristão na Pedagogia Freireana. Para tanto, busca-se no pensamento personalista de Emmanuel Mounier entender algumas destas condições de possibilidade. $\mathrm{O}$ artigo está organizado em três momentos: o primeiro aborda as principais concepções humanistas; o segundo analisa o entendimento de homem em Paulo Freire e as possíveis aproximações com o pensamento mouneriano; como finalização, há uma provocação para se pensar sobre a produção do humano, imanente a este mundo.
\end{abstract}

Palavras-chave: Educação. Pedagogia Freirena. Humanismo cristão. Michel Foucault.

\begin{abstract}
The paper is part of a dissertation whose research problem is investigating which humanism discourses produce the education field in Paulo Freire's
\end{abstract}

\footnotetext{
* Pesquisa financiada pela CAPES e pelo CNPq.

** Doutoranda do PPG Educação Ambiental da Universidade Federal do Rio Grande/ FURG. Mestre em Educação em Ciências pela Universidade Federal do Rio Grande/ FURG. Bolsista CAPES. E-mail: barbaragarre@gmail.com

**** Professora do Instituto de Educação e dos Programas de Pós-Graduação em Educação Ambiental e Educação em Ciências da Universidade Federal do Rio Grande/FURG. Doutora em Educação pela Universidade do Vale dos Sinos/UNISINOS. E-mail: paula. henning@ig.com.br
} 
perspective. The choice of the discursive corpus lays on the understanding that Paulo Freire is a strong author on the education field, being a fundamental reference in the Teaching Plans and Curriculums of teacher training courses. Here we aim to reassemble some genealogical traces that constitute themselves as possibility conditions for the emergence of a Christian humanist thinking in Freire's pedagogy. So, with Emmanuel Mounier's Personalism we seek to understand some of these possibility conditions. The paper has been organized in three moments: the first one approaches the main humanistic conceptions; the second one analyzes Paulo Freire's understanding of mankind and the possible approximations with Mounier's thinking; and at last, there is a provocation for us to think about the production of human being, immanent to this world.

Keywords: Education. Freire's Pedagogy. Christian humanism. Michel Foucault.

\section{Contextualização}

O presente artigo é desdobramento de uma dissertação que investiga quais discursos de humanismo produzem o campo da educação, na perspectiva freireana. Nossa intenção neste texto é fazer um recorte e problematizar alguns desses discursos recorrentes na atualidade, especialmente em duas obras de Paulo Freire, Pedagogia do oprimido ${ }^{1}$ e Pedagogia da autonomia ${ }^{2}$.

Pretendemos remontar algumas pistas genealógicas ${ }^{3}$ que se constituem como condição de possibilidade para a emergência de um

\footnotetext{
1 Cf. FREIRE (1981).

2 Cf. FREIRE (2001).

3 Para operarmos com as pistas genealógicas, tomamos o conceito foucaultiano de genealogia como referência, aquele emprestado de Friedrich Nietzsche. Entendemos essa ferramenta metodológica como estratégia analítica, como tática que se detém em estudar as condições de possibilidade para a emergência de um determinado campo do saber. Não remontamos o pensamento freireano em busca de reconstituir uma origem, mas o remexemos minuciosamente para entender algumas condições que o produziram. "[...] a genealogia é a tática que, a partir da discursividade local assim descrita, ativa os saberes libertos da sujeição que emergem desta discursividade" (FOUCAULT, 1990, p. 172).
} 
pensamento humanista cristão na Pedagogia Freireana ${ }^{4}$. Para tanto, buscamos no pensamento personalista de Emmanuel Mounier entender algumas destas condições de possibilidade.

Destacamos que a escolha do corpus discursivo em discussão nesta pesquisa situa-se no entendimento de que Paulo Freire é um autor muito potente no campo da educação, da formação de professores e especialmente da Pedagogia. A potência de seu pensamento é reforçada ainda mais quando, no ano de 2009, foi criada uma plataforma de educação a distância com seu nome: Plataforma Paulo Freire. Tal espaço tem como objetivo central levar a formação continuada de professores aos locais de mais difícil acesso no Brasil. Por entendermos o sucesso do pensamento freireano nas obras: Pedagogia do oprimido e Pedagogia da autonomia, que se encontram atualmente na $49^{\mathrm{a}}$ e $40^{\mathrm{a}}$ reimpressão, respectivamente, e que ganham lugar de destaque nos cursos de formação de licenciatura é que justificamos nossa escolha. Vale ressaltar que em pesquisa prévia, acerca das obras mais utilizadas em cursos que formam professores, identificamos o autor Paulo Freire com grande força nos Planos de Ensino analisados por diferentes instituições de Ensino Superior de nosso País. Entre os cursos, como: Pedagogia, Ciências Biológicas, Química e Matemática foram analisadas disciplinas referentes à formação de professores. Esse estudo foi realizado, fazendo análise dos Planos de Ensino, em diferentes Instituições de Ensino Superior no Brasil.

O legado freireano deixou muitas contribuições teóricas. Enfatizamos neste trabalho as questões referentes ao processo de humanização, no qual é fundamental o exercício da tríplice-relação entre a visão de mundo, a de homem e a de sociedade. $\mathrm{O}$ compromisso situado por Freire é com a mudança, com a "transformação do mundo", propondo uma educação integral do ser humano, que será alavanca para o desenvolvimento social.

A obra Pedagogia do oprimido foi escrita durante seu exílio no Chile onde, durante cinco anos, desenvolveu trabalhos em programas de educação de adultos no Instituto Chileno para a Reforma Agrária (ICIRA).

4 Optamos por utilizar letras maiúsculas ao tratarmos da Pedagogia Freireana por entendermos que tal pensamento constituiu-se como hegemônico no campo da educação. 
Sua prisão (após o Golpe Militar de 1964) e seu posterior exílio ocorreram pela acusação de ter subvertido a ordem instituída através da propagação de sua metodologia de alfabetização.

Paulo Freire é um autor reconhecido no Brasil e no mundo, e isto é notável no fato do livro, em questão, ter sido traduzido em mais de vinte idiomas. Freire recebeu diversos títulos, sendo cidadão honorário de várias cidades. A ele foi outorgado o título de doutor Honoris Causa por 27 universidades, além de receber muitos $\operatorname{prêmios}^{5}$ na área da educação. Ainda hoje, após 13 anos de sua morte, muitas Universidades mantêm a cátedra Paulo Freire, entre elas estão: a Pontifícia Universidade Católica de São Paulo e a Universidade Federal da Paraíba.

Pedagogia da autonomia foi o último livro lançado pelo educador Freire, em abril de 1997 - ano de sua morte. Nesta obra há uma preocupação em propor uma prática educativa voltada para o desenvolvimento do educando; prática que só é possível através do diálogo permanente. Nesta concepção, o diálogo é entendido como uma postura diante do mundo, dos outros e do conhecimento. De tal modo, no discorrer de sua escrita evidencia os saberes docentes necessários a uma prática educativa que se pretenda libertadora, através de uma postura dialógica.

Segundo alguns importantes estudiosos do pensamento freireano, como Balduíno Andreola, Danilo Streck, Gilberto Kronbauer e Gomercindo Ghiggi, há uma forte influência do pensamento existencialista e do pensamento marxista na Pedagogia de Paulo Freire. Assim, autores como Kant, Marx, Engels e Gramsci constituem-se como importantes fontes inspiradoras de sua obra. No que se refere à reflexão humanística e à aproximação com a teologia da libertação, destacamos o pensador existencialista cristão Emmanuel Mounier, como importante interlocutor da produção freireana, segundo Balduíno Andreola:

Podemos falar em duas categorias de relações: relações de influências e de convergências. As de influências é o próprio Freire que as

5 Alguns entre os prêmios que Freire recebeu são: "Prêmio Rei Balduíno para o Desenvolvimento" (Bélgica, 1980); "Prêmio UNESCO da Educação para a Paz" (1986); "Prêmio Andres Bello" da Organização dos Estados Americanos, como Educador do Continente (1992). 
reconhece. Ao falar de pensadores franceses nos quais se inspirou, cita, sobretudo, Bernanos, Maritain e Mounier. Além das leituras diretas, Freire viveu a influência de Mounier em dois contextos: no Movimento de Cultura Popular (MCP) do Recife, fundado por Germano Coelho, e nos grupos dos católicos de esquerda, sobretudo a Ação Católica e a $\mathrm{AP}^{6}$. Às convergências entre o projeto políticopedagógico do personalismo de Mounier e o projeto pedagógicopolítico da pedagogia do oprimido, de Freire, dediquei toda a minha tese de doutorado. O personalismo de Mounier, como projeto políticopedagógico de uma nova civilização, e a pedagogia do oprimido de Freire, como projeto pedagógico-político de libertação, convergem na utopia emancipatória de construção de uma nova civilização, mais humana e solidária (Revista IHU On-Line, 2005).

Nas obras freireanas em estudo emerge uma preocupação e valorização constantes do humano: um ser que busca conhecer a si mesmo e ao se conhecer toma consciência de sua incompletude enquanto ser inconcluso, inacabado. Para Freire, a busca pela humanização dos homens é permanente e se dará pela via da educação, tendo no diálogo, a concretização desta possibilidade. A comunhão, o testemunho ético, a convivência com os mais necessitados são condições fundamentais no processo de construção de uma sociedade mais justa e humana. O homem, nesse sentido, torna-se um ser para si vivendo com os outros. $\mathrm{O}$ reconhecimento do humano, como sujeito de sua práxis, a "afirmação dos homens, como pessoas" são apresentadas como condições necessárias ao processo de humanização.

Neste sentido, entendemos que colocar a obra freireana em exame exige: olhar o pensamento humanista existencialista cristão e entender suas aproximações com o Personalismo ${ }^{7}$ de Emmanuel Mounier (filósofo francês do século XX). A escolha por Mounier se deve por entendermos que é um autor pouco estudado no campo da educação, diferente de Marx,

\footnotetext{
6 A sigla AP significa Ação Popular que lutava pelo socialismo humanista na década de 1960.

7 O Personalismo é considerado como importante movimento humanista, que tem como líder Emmanuel Mounier. O autor nos diz que o personalismo seria uma Pedagogia que pensa o homem em sua liberdade, em sua existência como um todo.
} 
que vem sendo muito explorado em trabalhos freireanos. Neste sentido, olhar as obras em estudo nesta dissertação aproximando-as do pensamento mouneriano constitui-se como um desafio para nós. Queremos com esse trabalho provocar nosso pensamento e dos possíveis leitores, quanto aos cruzamentos teóricos entre Freire e Mounier, que pautam seus estudos, na busca pela comunhão, pelo testemunho ético, pela defesa de um sujeito oprimido em processo de humanização.

No presente trabalho retomamos algumas conceituações quanto ao pensamento humanista, buscando entender suas diferentes concepções. O autorPedro Nogare(2008), importante estudioso de Filosofia eAntropologia, nos subsidia teoricamente nessa empreitada. Não pretendemos tomar um único conceito como válido, ou um conceito mais apropriado, mas entender a diversidade teórica de concepções que tem versado acerca do pensamento humanista. Fazemos tal operação para chegar ao humanismo existencialista cristão, realizando alguns cruzamentos com a concepção de homem de Paulo Freire. Para tanto, organizamos o artigo em três momentos: 1) abordamos as principais concepções humanistas, destacando alguns dos seus pontos importantes; 2) analisamos o entendimento de homem em Paulo Freire e as possíveis aproximações com o pensamento Mouneriano e 3) como tentativa de um fechamento provisório, provocamo-nos a pensar sobre a produção do humano não transcendental, mas imanente a este mundo.

\section{O humanismo como condição para se tornar um verdadeiro homem}

De acordo com Pedro Nogare (2008), há três sentidos fundamentais para o termo humanismo, ou seja, que se relacionam entre si, são eles: o humanismo histórico literário, o humanismo de caráter especulativofilosófico e o humanismo de caráter ético-sociológico. No primeiro, encontramos o humanismo que estuda os grandes autores da cultura clássica, grega e romana. Já no segundo, encontramos uma gama de concepções que divergem entre si, são elas: o humanismo antigo, o humanismo cristão, o humanismo moderno e o humanismo contemporâneo. Ao falar sobre o terceiro sentido, o autor situa o humanismo como prática, como concretização, indo além do plano de contemplação do mundo. 
Neste trabalho faremos um rápido panorama do humanismo, pelo viés do segundo sentido proposto por Nogare, abordando o humanismo antigo, o humanismo renascentista, o humanismo marxista e o humanismo existencialista cristão.

Ao tratar do humanismo antigo, destacamos que toda e qualquer forma de humanismo, inclusive o nosso, Ocidental, tem suas raízes na história da civilização grega. Para entender esta vinculação é preciso conhecer um pouco do pensamento grego e de como se fundamenta esta civilização. $\mathrm{Na}$ atualidade muitos pensadores têm tomado as ideias dos sofistas como importantes pontos para a formação do humanismo. Para esses filósofos, a preocupação com o humano era central, quase exclusiva, diferente dos pré-socráticos. A partir dos sofistas, a educação deixa de ser privilégio de uma minoria, passando a ser um princípio de fácil acesso a todos.

Amáxima "conhece-tea timesmo"influenciou de forma significativa o pensamento humanista ocidental, sendo esta um ponto fundamental de constituição do humanismo. Os dois grandes discípulos de Sócrates, Platão e Aristóteles, reverberaram seu entusiasmo pela reflexão filosófica, pela verdade e pela virtude. Platão, filósofo conhecido pela divisão do mundo em dois, o das Ideias e o das Aparências, é reconhecido como aquele que problematiza a questão do espírito e da matéria, da alma e do corpo. Para ele, o mundo real é o mundo das ideias, que são infinitas, eternas e imutáveis, é o mundo da luz. Já o nosso mundo seria aquele das aparências, que é limitado, que se modifica e, portanto, seria o mundo das sombras. De acordo com Platão, alma e corpo jamais formarão uma unidade, serão sempre opostos, permanecerão em luta. O homem verdadeiro, na perspectiva platônica, seria o homem da razão, do espírito e da contemplação. Em Aristóteles alma e corpo estão unidos intimamente no homem, formando uma só realidade. Assim, o homem seria composto de alma e corpo. No pensamento aristotélico, a alma representa algo de divino no homem.

Com este breve apanhado podemos afirmar que na antiguidade grega o homem assume lugar privilegiado, havendo uma ênfase do humano enquanto o autêntico ser, reconhecido em sua universalidade. Deste modo, é difícil separar o entendimento de humanismo que se constitui no Ocidente do pensamento filosófico dos gregos, pois "nosso humanismo é modelado pelo deles" (NOGARE, 2008, p. 25). 
No humanismo renascentista há uma busca, uma valorização intensa do antigo, no sentido de conhecer e entender o pensamento da antiguidade, como inspiração e não para simples reprodução de modelos. Isso ocorre especialmente na Itália. Muitos autores abordam como característica, também, fundamental da Renascença, um período de riqueza e fecundidade de artistas. Nogare coloca que não há outro período na civilização ocidental tão fértil de gênios. $O$ termo Renascença é utilizado para marcar a nova arte requintada em sentido oposto àquela dita "arte grosseira" dos séculos anteriores, assim como o surto de cultura em relação à barbárie. A Renascença conotaria um florescimento cultural geral.

$\mathrm{O}$ homem da Renascença tem um lugar neste mundo, sem negar a existência divina. $\mathrm{O}$ homem aqui não é aquele que fica no nível do pensamento e da reflexão, mas um homem que procura concretizar e experimentar sua capacidade. Neste movimento volta aos antigos em busca de um modelo, de uma diretriz, em busca de um exemplo perfeito de humanidade. Todo este interesse pelo homem visa, além da exaltação, também uma formação. E assim, surgem importantes educadores e uma preocupação com o comportamento do homem. Na Renascença, o homem modifica, melhora e recria o mundo, o universo, é um ser criativo. Essa concepção de homem como conhecedor e transformador promoveu o "avanço" de uma ciência no Renascimento, passando a ter uma nova relação com a natureza, querendo conhecê-la, explorá-la, colocando-a a seu serviço. Esta concepção em torno do humano, como um ser pensante e ativo, para além de um homem que é simplesmente espectador do universo, constitui importante princípio para a constituição de um pensamento humanista.

No pensamento humanista marxista o ser humano é considerado, por um lado, um ser natural e, por outro, possui uma especificidade que o identifica como "humano", esta característica é a sociabilidade, a capacidade de formar uma sociedade. Nessa sociedade, o homem através do trabalho, e em relação com os outros homens, assegura a satisfação de suas necessidades naturais, transformando a natureza, transformando-a e aproximando-a de sua humanidade.

O conceito de alienação é muito importante para entender o pensamento marxista e seu caráter humanista. Para Marx, a alienação é 
histórica, colocando ainda esta característica na própria condição humana. A condição alienada do homem pode ser em relação à religião, à ideologia, à política e à economia. Esta última entendida como determinante das outras. Para o marxismo, a libertação da alienação seria uma condição que ainda estaria por vir; nela o homem atingiria sua real liberdade.

O conceito de homo faber é também de extrema relevância na teoria marxista. A partir deste entendimento, o homem é aquele cria e é criado pelo trabalho, encontrando na dialética o ponto de partida para esta criação. Do mesmo modo, o homem no pensamento marxista é concebido como aquele que "humanizando a natureza pelo trabalho, se cria ele mesmo homem, se torna produtor de si mesmo" (NOGARE, 2008, p. 102). Na perspectiva humanista existencialista, encontramos duas correntes muito fortes, a dos ateus e a dos cristãos. Para os existencialistas, a existência precede a essência, não havendo predefinição do ser, o homem é um ser único que experimenta, que é dono de seu destino e de suas ações. Na visão ateísta, ironicamente, não importa o que o homem faça para melhorar sua própria existência ou a dos outros, pois no final a deterioração e a morte são inevitáveis. Dessa forma, o homem é aquilo que faz da sua própria vida, só existindo na medida em que vive e se realiza. Já para os cristãos, a existência autêntica é aquela que liga a Deus, a fé e a crença religiosa. É uma existência alicerçada na transcendência, na qual a relação com Deus é um dado essencial para a elucidação da situação humana.

Para Nogare (2008), o filósofo Gabriel Marcel é o pensador do existencialismo cristão que mais se aproxima de Kierkegaard (considerado o iniciador do existencialismo). Em Marcel o homem é um ser encarnado, que busca a descoberta de um sentido para a sua vida. Pensar em Deus é uma relação absolutamente incluída no ato de fé. Dessa forma, a existência humana é um encontro pessoal entre Deus e o eu. A comunhão aparece em seu pensamento como uma comunhão autêntica, na qual o outro é reconhecido como presença. No pensamento existencialista cristão de Gabriel Marcel, Deus é presença absoluta.

Emmanuel Mounier se aproximou do pensamento de Marcel na produção de sua filosofia personalista. O tema central de sua concepção teórica é a pessoa como vocação, encarnação, comunicação e engajamento. Para o autor, a relação autêntica entre os homens ganha destaque na 
construção de uma civilização personalista. Remontamos este pensamento por visualizarmos potentes aproximações entre sua perspectiva de estudos e a Pedagogia de Paulo Freire, como já anunciado no começo deste artigo.

Em Mounier há uma preocupação com o homem alienado e coisificado, com o homem que precisa ser libertado. A paixão pelos pobres e abandonados são traços marcantes de sua filosofia. Aposta nas relações entre as pessoas, no sentido de somar esforços, caminhando para a reinvenção das gentes e da sociedade como um todo. A busca pelo ser é uma busca incessante em sua obra, uma busca que supera a cultura do ter.

O filósofo Ricardo Timm de Souza (2004), ao falar da concepção de ser humano em Mounier, destaca:

Temos, portanto, uma visão bastante precisa da concepção de ser humano em Mounier. "Ser humano" é aquele que é capaz de resistir às seduções do mergulho no indiferenciado, ou em algum tipo de espiritualismo ou idealismo diáfano; ser humano é uma luta ativa contra essas tendências despersonalizantes, ou seja, alienantes, que fazem o núcleo subjetivo, a resistência ao indiferenciado que constitui originalmente a pessoa, estranhar-se de si mesmo, perder-se fora de si, em suas produções, meios de troca, ou na natureza "bruta" (SOUZA, 2004, p. 226, grifos do autor).

No pensamento mouneriano, as situações de injustiças e desigualdades, que promovem grande parte dos males do mundo, desencadeiam um processo de despersonalização do ser. Assim, o autor pretende superar a crise da pessoa através da restituição de seu lugar vital e existencial, fazendo-se necessária sua retomada, como ser relacional, em sua plenitude, em sua integridade - através do personalismo. O homem, nesta perspectiva, reconhece sua condição de existência, mas uma existência que não é apenas para si, mas sim compartilhada, na qual assume a tarefa de ajudar o outro a conquistar a sua dignidade.

A pessoa é uma existência capaz de se libertar de si própria, de se desapossar, de se descentrar para se tornar disponíveis aos outros. Para a tradição personalista (principalmente a cristã), a ascese do 
despojamento é a ascese central da vida pessoal; só liberta o mundo e os homens aquele que primeiramente se libertou a si próprio. Os antigos falavam da luta contra o amor-próprio; nós chamamos-lhe hoje egocentrismo, narcisismo, individualismo (MOUNIER, 2004, p. 47).

A pessoa ganha lugar privilegiado na obra de Mounier como ser inconcluso, incompleto e inacabado. Pessoa que é concebida na relação com os outros, pessoa na e para a comunidade. Aposta numa revolução personalista na educação, na qual as pessoas em comunhão superem suas condições alienantes, construindo uma sociedade mais humana, justa e fraterna.

Igualmente, entendemosqueopensamentohumanistadefendidopela Pedagogia de Freire se aproxima fortemente dos pressupostos humanísticos da filosofia personalista de Mounier, tendo como foco o homem, o homem em comunhão, o homem enquanto ser de moral, o homem em busca de autonomia e libertação, enfim o homem em busca de sua humanização.

A luta pela humanização, pelo trabalho livre, pela desalienação, pela humanização, pela afirmação dos homens, como pessoas, como "seres para si", não teria significação. Esta somente é possivel porque a desumanização, mesmo que um fato concreto na história, não é porém, destino dado, mas resultado de uma "ordem" injusta que gera a violência dos opressores e esta, o ser menos (FREIRE, 1981, p. 30) ${ }^{8}$.

Toda união dos oprimidos entre si, que já sendo ação, aponta outras ações, implica, cedo ou tarde, em que percebendo eles o seu estado de despersonalização, descubram que, divididos serão sempre presas fáceis do dirigismo e da dominação (FREIRE, 1981, p. 170, grifos nossos).

Diante de tanta ênfase ao humano, passaremos a tratar deste entendimento nas clássicas obras Pedagogia do oprimido e Pedagogia da autonomia aproximando do Personalismo mouneriano.

8 Optamos por colocar os excertos dos livros analisados em itálico para destacar das demais citações. 


\section{A visão de homem em Paulo Freire}

Nos enunciados das obras Pedagogia da autonomia e Pedagogia do oprimido emerge com muita potência a ênfase ao homem, que aparece como centro da proposta de educação freireana. Vale ressaltar que este homem não é qualquer indivíduo. Aqui é, especialmente, aquele que assume características de humildade, que é trabalhador, que busca sua autonomia e emancipação na luta com seus semelhantes. É um sujeito que, se reconhecendo enquanto humano, almeja a sua salvação. É um homem que busca através da comunhão ser mais, saber mais, transformar o mundo e a natureza. Nas palavras do próprio Freire:

A auto-suficiência é incompativel com o diálogo. Os homens que não têm humildade ou a perdem, não podem aproximar-se do povo. Não podem ser seus companheiros de pronúncia do mundo. Se alguém não é capaz de sentir-se e saber-se tão homem quanto outros, é que lhe falta ainda muito que caminhar, para chegar ao lugar de encontro com eles. Neste lugar de encontro, não há ignorantes absolutos, nem sábios absolutos: há homens que, em comunhão, buscam saber mais (FREIRE, 1981, p. 95, grifos nossos).

E é como seres transformadores e criadores que os homens, em suas permanentes relações com a realidade, produzem, não somente os bens materiais, as coisas sensiveis, os objetos, mas também as instituições sociais, suas idéias, suas concepções (FREIRE, 1981, p. 108, grifos nossos).

Uma das tarefas mais importantes da prática educativo-crítica é propiciar as condições em que os educandos em suas relações uns com os outros e todos com o professor ou a professora ensaiam a experiência profunda do assumir-se. Assumir-se como ser social e histórico, como ser pensante, comunicante, transformador, criador, realizador de sonhos, capaz de ter raiva porque capaz de amar. Assumir-se como sujeito porque capaz de reconhecer-se como objeto. A assunção de nós mesmos não significa a exclusão dos outros. É a "outredade" do "não eu”, ou do tu, que me faz assumir a radicalidade de meи eu (FREIRE, 2001, p. 46, grifos nossos). 
Colocamo-nos a pensar neste ser humilde, modesto, que se reconhece enquanto humano pela outredade. Inquieta-nos pensar que este entendimento de homem assume um lugar privilegiado na Pedagogia. Seguindo este viés, o processo educativo, na concepção freireana, pautase na supremacia do homem. Homem que aqui é o sujeito do bem, é vítima, é necessitado, ou, como diria Mounier (2004), "é um sujeito despersonalizado". Questionamos esta visão do homem como um ser supremo, um homem que pode tudo. Parece-nos contraditória essa ênfase ao humano, uma vez que é o próprio Freire que faz uma crítica ao homem como detentor do saber, ao homem dominador do mundo, ao homem que causa os males da sociedade, ao homem opressor ${ }^{9}$. Ora, o que nos parece é que outro tipo de homem é que assume o lugar privilegiado. A serviço deste humano está a natureza, o mundo, a ciência e a tecnologia. Dessa forma, aquele sujeito humilde, trabalhador, solidário acaba assumindo um ideal humanista de sujeito correto, de sujeito da justiça e da verdade.

Aqui aproximamos a supremacia do humano de Paulo Freire à visão de homem em Mounier, que também defende a ideia de um homem como centro, como supremo, argumentando quanto à impossibilidade da existência do mundo sem uma existência propriamente humana. "Cada vez mais a ciência e a reflexão nos revelam um mundo que não pode passar sem o homem e um homem que não pode passar sem o mundo" (MOUNIER, 2004, p. 35).

Na perspectiva defendida por Freire, a ciência, desde que leve o homem da condição alienada para uma condição humanamente esclarecida e consciente, é considerada como um saber importante e válido. O saber científico é, então, colocado a serviço do humano e da humanização da sociedade pela via da razão esclarecida. Nos excertos abaixo, tornase visível o papel conferido à ciência, que numa perspectiva humanista revolucionária estaria a serviço da humanização dos homens.

Se as elites opressoras se fecundam, necrofilamente, no esmagamento dos oprimidos, a liderança revolucionária somente na comunhão com

9 No próximo artigo desta dissertação trataremos de forma mais profícua deste entendimento de opressor e oprimido, nas obras freireanas em estudo. 
eles pode fecundar-se. Esta é a razão pela qual o quefazer opressor não pode ser humanista, enquanto o revolucionário necessariamente $o$ é. Tanto quanto o desumanismo dos opressores, o humanismo revolucionário implica na ciência. Naquele, esta se encontra a serviço de "reificação"; nesta, a serviço da humanização. Mas, se no uso da ciência e da tecnologia para "reificar", o sine qua non desta ação é fazer dos oprimidos sua pura incidência, já que não é o mesmo o que se impõe no uso da ciência e da tecnologia para a humanização. Aqui, os oprimidos ou se tornam sujeitos, também, do processo, ou continuam "reificados" (FREIRE, 1981, p. 155-156, grifos nossos).

$O$ progresso científico e tecnológico que não responde fundamentalmente aos interesses humanos, às necessidades de nossa existência, perdem, para mim, sua significação. A todo avanço tecnológico haveria de corresponder o empenho real de resposta imediata a qualquer desafio que pusesse em risco a alegria de viver dos homens e das mulheres (FREIRE, 2001, p. 147, grifos nossos).

Enunciados como estes, nos colocam a pensar na defesa do avanço tecnológico e científico, desde que estejam a favor do homem, do seu "bem-estar", da sua humanização. Entendemos que a primazia do humano, enquanto dominador e possuidor do mundo e da natureza fazem do homem não apenas um sujeito ativo que controla e domina, mas também um sujeito que é controlado e dominado. O homem como ser supremo, o homem acima de todas as coisas, o homem exaltado em sua condição de ser pensante aparecem como indicadores de uma filosofia humanista na perspectiva freireana. Nesta filosofia, o indivíduo torna-se sujeito de sua própria história conscientizando-se e reconhecendo sua condição de humano. Sua busca constante é pela superação das condições injustas e precárias das quais é submetido e, conseguindo, atingirá sua emancipação.

Remontamos aqui o entendimento de Maria Manuela Alves Garcia (2002) quanto às pedagogias que se pautam pela ênfase numa razão esclarecida - neste caso a ciência. Segundo a autora, para estas pedagogias, a educação é a possibilidade de levar o homem para uma condição melhor, para uma condição de pleno desenvolvimento da racionalidade. A educação 
assumida então como potencializadora, esclarecedora, conscientizadora, tornando os homens sujeitos plenos de seu processo de aprendizagem pelo viés da ciência.

A tarefa, "iluminadora", "esclarecedora" e "humanizadora" atribuída à escola e aos profissionais da educação e do ensino. O esclarecimento das consciências com as verdades propiciadas pela ciência e pela (auto-)reflexão. $\mathrm{O}$ acesso a formas superiores de pensamento $\mathrm{e}$ existência individual e social. A produção do sujeito ou do cidadão racional, maculino, (auto-) reflexivo e autônomo, ou seja, o sujeito ou a classe social plenamente desenvolvidos. A redenção e a salvação de si mesmo e da humanidade pelo poder libertador da razão e da ação (da agência humana) sintetizam os enunciados de pedagogias que se auto-intitulam pedagogias revolucionária, sócio-histórica, históricocrítica, crítico-social dos conteúdos, libertadora, da conscientização, da autonomia e da esperança, quando tratam das finalidades, das metas ou da teologia da educação e do trabalho didático pedagógico-crítico e progressista (GARCIA, 2002, p. 35, grifos da autora).

Na concepção freireana, assim como aparece em Mounier (2004), o homem se torna sujeito quando reconhece sua própria condição de humano, olhando para si, tomando consciência de sua condição e natureza humanas. Entendemos que esta possibilidade de olhar para si é marca de um campo de saber legitimado a estudar o humano. Este campo de saber denomina-se ciências humanas e aqui visualizamos, na Pedagogia, uma destas ciências que está a serviço do humano e que tem como atributo humanizar cada vez mais e cada vez melhor. Podemos perguntar, afinal, o que são as práticas pedagógicas de reflexão, de autoavaliação, de conscientização, que colocam constantemente os sujeitos a pensar sobre suas próprias ações. Entendemos que estas práticas são práticas que permitem um autoexame das consciências, um conhecer-se para autogovernar-se, cada vez mais e cada vez melhor.

É que não haveria ação humana se não houvesse uma realidade objetiva, um mundo como "não eu" do homem, capaz de desafiá-lo; 
como também não haveria ação humana se o homem não fosse um "projeto", um mais além de si, capaz de captar a sua realidade, de conhecê-la para transformá-la (FREIRE, 1981, p. 42, grifos nossos).

Mas, se os homens são seres do quefazer é exatamente porque seu fazer é ação e reflexão. É práxis. É transformação do mundo. $E$, na razão mesma em que o quefazer é práxis, todo fazer do quefazer tem de ter uma teoria que necessariamente o ilumine. O que fazer é teoria e prática. É reflexão e ação. Não pode reduzir-se, como salientamos no capitulo anterior, ao tratarmos a palavra, nem ao verbalismo, nem ao ativismo (FREIRE, 1981, p. 145, grifos nossos).

[...] a reflexão não é somente um olhar interior sobre mim e minhas imagens lançado; é também intenção, projeto de nós próprios. [...] A consciência íntima não serve de bastidores onde a pessoa entorpeça, é como a luz, presença secreta e no entanto irradiando para o mundo inteiro (MOUNIER, 2004, p. 61).

Vemos na Pedagogia uma forte preocupação em desenvolver saberes sobre o homem, sobre seu funcionamento, estudando-o e conhecendo-o para melhor controlá-lo, produzi-lo enquanto um ser dócil e útil. Seguindo a correnteza dos estudos de Foucault (2002), podemos dizer que as ciências humanas nascem numa tentativa de melhor conhecer o homem para melhor governá-lo. O homem se torna sujeito e objeto de sua própria pesquisa. Assim, as ciências humanas vivem um paradoxo: constituem o homem em sua dupla condição de sujeito que conhece e objeto do conhecimento. Ao mesmo tempo em que produz representações sobre sua própria condição de humano, produz formas de ser, estar e viver no mundo.

De um modo mais geral, o homem, para as ciências humanas, não é esse ser vivo que tem uma forma bem particular (uma fisiologia bastante especial e uma anatomia quase única); é esse ser vivo que, do interior da vida à qual pertence inteiramente e pela qual é atravessado em todo seu ser, constitui representações graças às quais ele vive e a partir das quais detém essa estranha capacidade de poder se representar justamente a vida (FOUCAULT, 2002a, p. 487). 
As ciências humanas buscam representar a própria vida no momento em que estudam o homem em toda a sua complexidade, até o mais ínfimo movimento, estudam no detalhe, conhecem o homem e suas formas de ser, de se relacionar, de conviver, de aprender. Nos materiais analisados, a Pedagogia Freireana produz uma forma de ser do humano, prescreve práticas almejando humanizar a sociedade e o próprio homem. Tal Pedagogia coloca o homem num movimento de se (re)conhecer e se autoavaliar constantemente. Vemos nesse exercício do homem de olhar para si uma estratégia de autogoverno, de controle das condutas. Nas palavras de Veiga-Neto "[...] nos tornamos sujeitos pelos modos de investigação, pelas práticas divisórias e pelos modos de transformação que os outros aplicam e que nós aplicamos sobre nós mesmos" (2003, p. 136).

A existência, porque humana, não pode ser muda, silenciosa, nem tampouco pode nutrir-se de falsas palavras, mas de palavras verdadeiras, com que os homens transformam o mundo. Existir, humanamente, é pronunciar o mundo, é modificá-lo. $O$ mundo pronunciado, por sua vez, se volta problematizado aos sujeitos pronunciantes, a exigir deles novo pronunciar (FREIRE, 1981, p. 92, grifos nossos).

Os homens, pelo contrário, ao terem consciência de sua atividade e do mundo em que estão, ao atuarem em função de finalidades que propõem e se propõem, ao terem o ponto de decisão de sua busca em si e em suas relações com o mundo, e com os outros, ao impregnarem o mundo de sua presença criadora através da transformação que realizam nele, na medida em que dele podem separar-se e, separandose podem com ele ficar, os homens, ao contrário do animal, não somente vivem, mas existem, e sua existência é histórica (FREIRE, 1981, p. 105, grifos nossos).

Ter a consciência crítica de que é preciso ser o proprietário de seu trabalho e de que "este constitui uma parte da pessoa humana" eque a "pessoa humana não pode ser vendida nem vender-se" é dar um passo mais além das soluções paliativas e enganosas. É inscrever-se numa ação de verdadeira transformação da realidade para, humanizando-a, humanizar os homens (FREIRE, 1981, p. 217, grifos nossos). 
Nesta correnteza, problematizamos o homem freireano e a pessoa mouneriana enquanto sujeitos plenos, humanizados, situados como um ponto de partida. O homem como pronunciante do mundo e fazedor de sua história é concebido por estas perspectivas humanistas cristãs, que defendem a busca pela desalienação, pela emancipação e libertação. Para estas vertentes teóricas, o homem atinge sua libertação pela via do diálogo e da comunhão e, enquanto sujeito livre, autocentrado e consciente, assume a missão de ajudar o outro alienado, a alcançar a sua dignidade.

A pessoa é uma existência capaz de se libertar de si própria, de se desapossar, de se descentrar para se tornar disponíveis aos outros. Para a tradição personalista (principalmente para a cristã), a ascese do despojamento é a ascese central da vida pessoal; só liberta o mundo e os homens aquele que primeiramente se libertou a si próprio (MOUNIER, 2004, p. 47).

Vemos que esse sujeito que liberta a si e aos outros é a utopia pedagógica do sujeito livre e emancipado, do ideal de ser cidadão - que é almejado por estas perspectivas teóricas. A partir de Foucault (1995), entendemos que o próprio conceito de sujeito deve ser olhado com desconfiança, pois no entendimento do autor:

(...) Há dois significados para a palavra sujeito: sujeito a alguém pelo controle e dependência, e preso à sua própria identidade por uma consciência ou autoconhecimento. Ambos sugerem uma forma de poder que subjuga e torna sujeito a (...) (FOUCAULT, 1995, p. 235).

Na correnteza foucaultiana, não existe um sujeito que estaria dado, um sujeito que teria uma natureza humana, uma essência e que precisaria ser educado, levado a autoconscientizar-se. Dessa forma, problematizamos o entendimento de homem e o processo pelo qual os indivíduos se humanizam, "[...] se transformando em reais sujeitos da construção e da reconstrução do saber ensinado, ao lado do educador" (FREIRE, 2001, p. 29). Entendemos o homem, ou a própria noção de sujeito, como uma fabricação, uma invenção tipicamente moderna. O homem não teria estado sempre ali a espera de ser moldado e muito menos existiria uma essência 
propriamente humana, ou uma origem a ser resgatada. Para Foucault, o homem é uma produção; o homem é constituído a partir de diferentes práticas discursivas e não discursivas; o homem é um produto cultural. Há uma desconfiança a toda crença humanista, de teorizações que se pautam numa essência humana. Os ideais de homem são colocados em suspenso.

Entendemos que colocar a ênfase no humano, seja ele opressor ou oprimido, personalizado ou despersonalizado, tem sido a tradição do campo do saber das ciências humanas e aqui especialmente da Pedagogia. Vemos no material analisado o alastramento de tal objetivo, traçando um tipo ideal e universal de homem. Dessa forma, a utopia pedagógica do professorado tem sido formar um cidadão do bem, sujeito de sua aprendizagem, acreditando numa essência que precisa ser resgatada, libertada e colocada no caminho certo, no caminho da verdade, no caminho de uma educação humanizada e humanizadora. Ora, olhamos com desconfiança para tal ideologia que se funda na tradição humanística, que se pauta por valores cristãos, que coloca o humano num pedestal. Provocamo-nos a pensar num humano que vive neste mundo e produz algumas coisas, assim como é produzido por elas. Num homem que assume posições de sujeito para além de binarismos, tão caros às pedagogias libertadoras. Pensemos num humano para além do bem e do mal.

\section{A produção do humano, de um humano que é deste mundo}

Ao nos desafiarmos na empreitada de fechar este artigo, provocamos um questionamento quanto ao ideal de homem defendido pelas Pedagogias Libertadoras Freireanas: seria possível conceber o homem, enquanto um ser universal, autocentrado que se tornaria melhor pela via do esclarecimento e da conscientização? Esta tem sido uma forte bandeira freireana e que encontra ressonância no campo da educação. Então nos lançamos a pensar na contramão desta visão humanística, entendendo que não há uma essência verdadeiramente humana, precisando ser conscientizada e esclarecida. Olhamos com desconfiança para toda a crença apriorística, que tem como alvo (re)colocar o indivíduo na busca constante por sua salvação e redenção, para posteriormente, lutar com os outros para a libertação de todos. 
Incomodadas com algumas narrativas freireanas de humanização dos homens, de defesa da educação como conscientizadora e salvadora do humano, do homem como sujeito do amor e da justiça, buscamos neste artigo traçar algumas pistas genealógicas e problematizar a Pedagogia de Paulo Freire. Identificamos no pensamento humanista cristão uma forte aproximação. Há na visão humanista freireana uma ênfase ao homem e à defesa por uma sociedade que precisa ser humanizada pela via educativa. Encontramos em Emmanuel Mounier, filósofo do século XX, uma perspectiva teórica estreita à de Paulo Freire. A preocupação com o homem alienado e oprimido, com a sua libertação em comunhão com os outros, são pressupostos comuns a estes dois pensadores. Eles almejam a transformação do mundo, construindo uma sociedade livre de dependências, na qual o homem assume-se enquanto sujeito humanizado.

A grande generosidade está em lutar para que, cada vez mais, estas mãos sejam de homens ou de povos, se estendam menos, em gestos de súplica. Súplica de humildes e poderosos. E se vão fazendo, cada vez mais, mãos humanas, que trabalhem e transformem o mundo. Este ensinamento e este aprendizado têm de partir, porém, dos "condenados da terra", dos oprimidos, dos esfarrapados do mundo e dos que com ele realmente se solidarizem. Lutando pela restauração de sua humanidade estarão, sejam homens ou povos, tentando a restaurar da generosidade verdadeira (FREIRE, 1981, p. 32, grifos nossos).

Poderemos ver agora o paradoxo central da existência pessoal. Este é o modo especificamente humano de existir. Deve ser, no entanto, incessantemente conquistada; só muito lentamente é que a consciência se vai libertando do mineral, da planta ou do animal que em nós pesam. A história da pessoa será assim paralela a história do personalismo. Não se desenvolverá somente no plano da consciência, mas, em toda a sua grandeza, no plano do esforço humano para humanizar a humanidade (MOUNIER, 2004, p. 17, grifos nossos).

Seguindo o pensamento de Foucault, queremos escapar destas filosofias, oumelhor, desteshumanismos queproclamamumaideiadehomem como fonte significadora de verdade. Não queremos com isto fundar um novo 
modo humanista, um novo ideal de sujeito. Nossa intenção é movimentar as convicções serenas de ter um caminho a seguir, um ideal a alcançar. Colocamos em discussão algumas concepções universalistas, que se pautam num exemplo, que prescrevem a educação, o sujeito e a própria Pedagogia.

O que me assusta no humanismo é que ele apresenta uma certa forma de nossa ética como um modelo universal válido para qualquer tipo de liberdade. Penso que nosso futuro comporta mais segredos, liberdades possíveis e invenções do que o humanismo nos permite imaginar, na representação dogmática que fazem dele os diferentes componentes do espectro político: a esquerda, o centro e a direita (FOUCAULT, 2006, p. 300).

Com isso, queremos disparar o pensamento no sentido de produzirmos outras possibilidades éticas e estéticas para o homem e para nós mesmos enquanto humanos, mas não uma ética universal e atemporal. Talvez valesse pensar em uma ética como existência singular, micro, política, exercício de vida. Vale inquietar o pensamento e provocar nossas mais sólidas verdades inerentes ao campo educacional.

\section{Referências}

ANDREOLA, B. Os projetos pedagógicos-políticos de Mounier e Paulo Freire, Revista IHU on-line, São Leopoldo, Ed. 155, ano V, p. 14-17, Set. 2005. Entrevista concedida a IHU on-line. Disponível em: $<$ http://www. ihuonline.unisinos.br/media/pdf/IHUOnlineEdicao155.pdf $>$. Acesso em: 10 Fev. 2011.

FOUCAULT, Michel. Microfisica do poder. 17. ed. Rio de Janeiro: Graal, 1990.

.O sujeito e o poder. Apêndice da $2^{\mathrm{a}}$ edição. Michel Foucault entrevistado por Hubert L. Dreyfus e Paul Rabinow. In.: DREYFUS, Hubert; RABINOW, Paul. Michel Foucault, uma trajetória filosófica: para além do estruturalismo e da hermenêutica. Rio de Janeiro: Editora Forense Universitária, 1995. 
Editora Vozes, 2002.

. Vigiar e punir: história da violência nas prisões. 25. ed. Petrópolis: . As palavras e as coisas: uma arqueologia das ciências humanas. 8. ed. São Paulo: Martins Fontes, 2002a.

. Ditos e escritos $V$ - ética, sexualidade e política. 2. ed. Rio de Janeiro: Forense Universitária, 2006.

FREIRE, Paulo. Pedagogia do oprimido. 9. ed. Rio de Janeiro: Paz e Terra, 1981.

FREIRE, Paulo. Pedagogia da autonomia: saberes necessários à prática educativa. 18. ed. São Paulo: Paz e Terra, 2001.

GARCIA, Maria Manuela Alves. Pedagogia crítica e subjetivação. Petrópolis: Vozes, 2002.

MOUNIER, Emmanuel. O personalismo. São Paulo: Centauro, 2004.

NOGARE, Pedro Dalle. Humanismos e anti-humanismos - introdução à antropologia filosófica. 14. ed. Petrópolis: Vozes, 2008.

SOUZA, Ricardo Timm de. As fontes do humanismo latino. Vol 2. A condição humana no pensamento filosófico contemporâneo. Porto Alegre: EDIPUCRS, 2004.

VEIGA-NETO, Alfredo. Foucault e a educação. Belo Horizonte: Autêntica, 2003.

Data de registro:27/08/2011

Data de aceite:03/10/2012 